\title{
Utilization of Pure Silica Extracted from Rice Husk and FTIR Structural Analysis of the Prepared Glasses
}

\author{
H. A. Saudi ${ }^{1, \text { * , S. M. Salem }}$, S. S. Mohammad ${ }^{2}$, A. G. Mostafa ${ }^{2}$, M. Y. Hassaan² \\ ${ }^{1}$ Department of Physics, Faculty of Science, Al-Azhar University, Nasr City, Cairo, Egypt \\ ${ }^{2}$ Department of Physics, Faculty of Science (Girls' Branch), Al-Azhar University, Nasr City, Cairo, Egypt
}

Email address:

heba_saudi@yahoo.com (H. A. Saudi)

\section{To cite this article:}

H. A. Saudi, S. M. Salem, S. S. Mohammad, A. G. Mostafa, M. Y. Hassaan. Utilization of Pure Silica Extracted from Rice Husk and FTIR Structural Analysis of the Prepared Glasses. American Journal of Physics and Applications. Vol. 3, No. 3, 2015, pp. 97-105.

doi: 10.11648/j.ajpa.20150303.16

\begin{abstract}
Egyptian rice husk was subjected to different chemical and thermal treatment methods, aiming to extract high pure silica. Three samples $\left(\mathrm{S}_{1}, \mathrm{~S}_{2}\right.$ and $\left.\mathrm{S}_{3}\right)$ were prepared applying three different chemical treatment methods. Two sets of the obtained samples were prepared, where the first set was calcinated at $600^{\circ} \mathrm{C}$ and the other set was calcinated at $750{ }^{\circ} \mathrm{C}$ by slow heating (starting at RT and ending at the desired calcinations temperature for $2 \mathrm{~h}$ ).XRF was applied to identify the chemical composition and purity of the extracted silica, while XRD was applied to confirm the amorphous nature and the presence of some induced carbon black in the obtained silica. It was found that $\mathrm{S}_{3}$ slowly heated at $750{ }^{\circ} \mathrm{C}$ presents the highest silica content $(98.6 \%)$. Such sample was fed directly to the calcinations furnace at $750{ }^{\circ} \mathrm{C}$ (sudden heating for comparison) where it presents only $90.6 \%$ silica, and $3.74 \%$ residual carbon black. However, the extracted silica from sample $\mathrm{S}_{3}$ was used to prepare glasses obeying the composition (75-x) mol\% RH-silica, $\mathrm{x} \mathrm{mol} \% \mathrm{Bi}_{2} \mathrm{O}_{3}, 25 \mathrm{~mol} \% \mathrm{Na}_{2} \mathrm{O}$, (where $0 \leq \mathrm{x} \leq 20$ ).FTIR spectroscopic analysis was applied to investigate the internal structure of the prepared glasses, where the glass networks were found to contain mainly $\mathrm{SiO}_{4}, \mathrm{BiO}_{3}$ and $\mathrm{BiO}_{6}$ structural groups, as well as some bridging and non-bridging oxygen anions. Also, some O-H and $\mathrm{H}-\mathrm{O}-\mathrm{H}$ groups were also detected which may be due to the used $\mathrm{KBr}$ disk technique.
\end{abstract}

Keywords: Silica from Rice Husk, Silicate Glasses, Bi-Na-Silicate Glass, XRD, XRF, Infrared Spectroscopy

\section{Introduction}

Rice is a primary source of food for billions of people and it covers about $1 \%$ of the earth's surface. It ranks as the second to wheat in terms of area and production. Globally, approximately 600 million tones rice are produced each year, and for every $1000 \mathrm{~kg}$ of paddy milled, about $220 \mathrm{~kg}$ of rice husk ( $\mathrm{RH}$ ) is produced (about 22\%). RH is therefore an agricultural residue, and it is either burnt or dumped as waste $[1,2]$. Little of the $\mathrm{RH}$ is converted into useful end products such as feedstock [3], adsorbent [4], etc., while the most has burnt openly, causing environmental and health problems especially in poor and developing countries. Therefore, it is very important to find other pathways to utilize rice husk.

It was discovered as early as 1938 that silica can be extracted from $\mathrm{RH}$ as sodium silicate by using different extraction methods $[5,6]$. Its potential recovery had been realized since 1984 [7], where RH can be considered a good source of silica. It was found that silica in $\mathrm{RH}$ undergoes structural transformations depending on the conditions of combustion (time and temperature). Accordingly the extracted silica has different properties and it is important to treat $\mathrm{RH}$ by the correct specification for particular end use (See Fig. (1))[8]. Even though the use of silica extracted from $\mathrm{RH}$ is still limited.

It was found that, $\mathrm{RH}$ contains silica in the range of $20-25$ wt $\%$, in an amorphous form like silica gel [9-10]. Thermal degradation and pyrolysis of $\mathrm{RH}$ followed by combustion of the char result in highly porous and amorphous silica with a varying percentage of unburned carbon [11].

According to Kapur [11], when RH is burnt under controlled conditions, the resulting ash is considered, the cheapest bulk source of highly reactive silica. Furthermore, since the ash is obtained as a fine powder, it does not require further grinding [12] and thus, making it the most economical source of Nano-scale silica [13]. 
As reviewed also by Real et al [9], a number of published literatures $[14,15]$ had concluded that $\mathrm{RH}$ are an excellent source of high-grade amorphous silica. The silica obtained from $\mathrm{RH}$ ash is a good material for synthesis of very pure silicon [16-18], silicon nitride [19], silicon carbide [20, 21] and magnesium silicide [22]. In addition, the obtained silica has been claimed [17,18 and 23] to be an excellent source of very pure silicon, useful for manufacturing solar cells and for photo-voltaic power generation as well as various types of semiconductors $[24,25]$.

Closer to home, rice production in Egypt is concentrated in the agricultural space around Nile-delta where nearly 8 million tons of rice are produced annually, leading to the generation of large volumes of rice husk as agricultural wastes. Uncontrolled burning is often considered the most cost-effective disposal method for such by-product. This seasonal and highly localized massive burning generates excessive air pollution that lowers air quality in the neighboring of Cairo, which has become a serious health concern for citizens and authorities.

However, in this article, a trial will be carried out aiming to enrich the silica produced from Egyptian RH via chemical and thermal methods. Then they obtained silica will be used to prepare some silicate glasses and the obtained samples will be characterized applying infrared analysis.

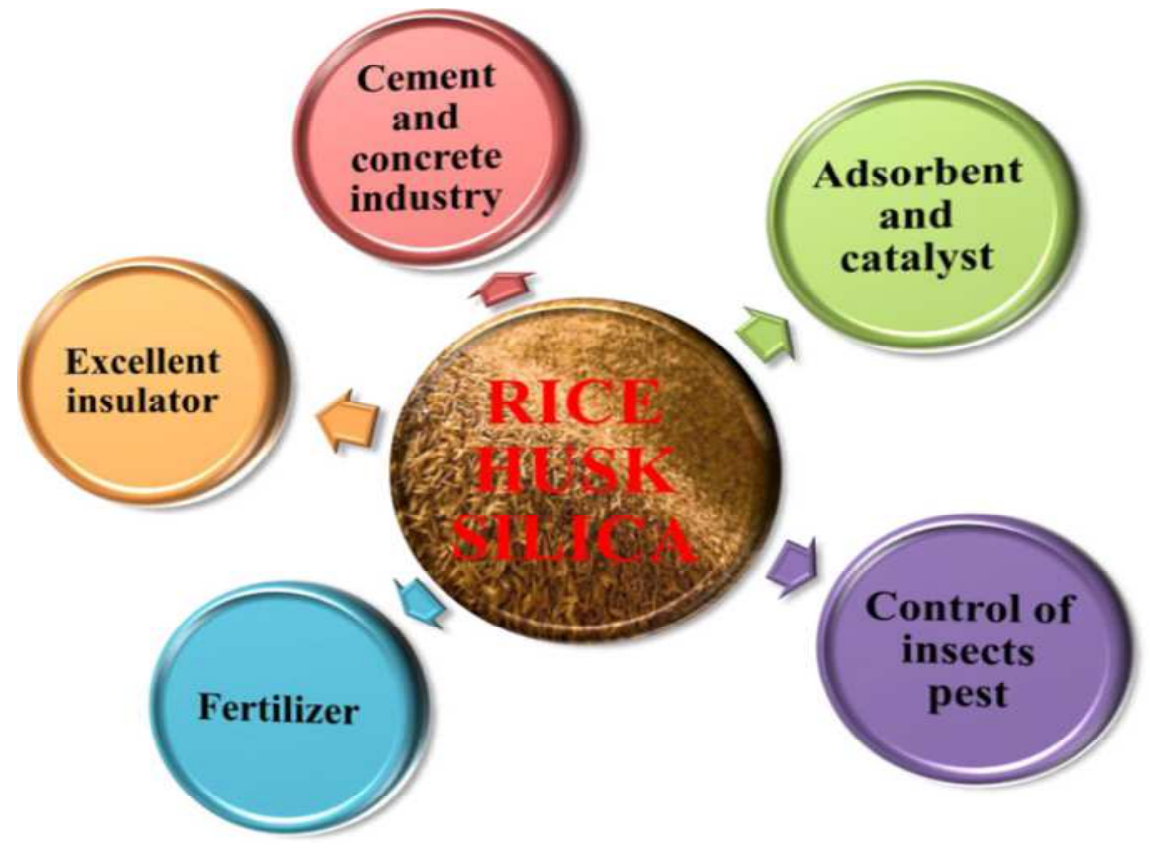

Fig. (1). Various utilizations of the RH silica. [8]

\section{Experimental Procedure}

Enrichment of silica:

The RH was provided from Banha, Al-Qalyobia, Egypt. Such RH was firstly combusted in open air to obtain non-acid leached and thermally untreated sample of RHA, only for comparison.

On the other hand, RH was subjected to acid leaching in three different ways to obtain three different samples applying different chemical treatment methods. The aim of this step is to improve the purity and the white color of the extracted silica [26-31].

The first sample $\left(\mathrm{S}_{1}\right)$ :

A $100 \mathrm{~g}$ sample of $\mathrm{RH}$ was fed into $3 \mathrm{~N} \mathrm{HCl}$ solution in de-ionized water, and boiled for $1.5 \mathrm{~h}$. After thorough washing with de-ionized water, the residue was filtered and finally dried in an oven at $100{ }^{\circ} \mathrm{C}$ for $1 \mathrm{~h}$.

The second sample $\left(\mathrm{S}_{2}\right)$ :

Another $100 \mathrm{~g}$ sample of RH was treated firstly by feeding into a solution consists of $(265 \mathrm{ml}$ ethyl alcohol and $735 \mathrm{ml}$ de-ionized water) and boiled for $1.5 \mathrm{~h}$. After thorough washing with de-ionized water, the residue was filtered and dried in an oven at $100^{\circ} \mathrm{C}$ for $1 \mathrm{~h}$. This sample was then fed into $3 \mathrm{~N} \mathrm{HCl}$ solution in de-ionized water, and boiled for $1.5 \mathrm{~h}$. After thorough washing with de-ionized water, the residue was filtered and finally dried in an oven at $100{ }^{\circ} \mathrm{C}$ for $1 \mathrm{~h}$.

The third sample $\left(\mathrm{S}_{3}\right)$ :

Similarly, another $100 \mathrm{~g}$ sample of RH was treated firstly by feeding into a solution consists of $(265 \mathrm{ml}$ ethyl alcohol and $735 \mathrm{ml}$ tap water) and boiled for $1.5 \mathrm{~h}$. After thorough washing with tap water, the residue was filtered and dried in an oven at $100{ }^{\circ} \mathrm{C}$ for $1 \mathrm{~h}$, and then this sample was fed into $3 \mathrm{~N} \mathrm{HCl}$ solution in a tap water, and boiled for $1.5 \mathrm{~h}$. After thorough washing with tap water, the residue was filtered and finally dried in an oven at $100{ }^{\circ} \mathrm{C}$ for $1 \mathrm{~h}$.

Two sets of the above obtained samples $\left(\mathrm{S}_{1}, \mathrm{~S}_{2}\right.$ and $\left.\mathrm{S}_{3}\right)$ were prepared in a way that, twenty gram of each sample were placed in porcelain crucibles and they were then introduced into an electrically heated muffle furnace where calcinations were conducted at 600 and $750{ }^{\circ} \mathrm{C}$ for each set respectively. In case of slow heating, the samples were loaded into the furnace at room temperature, and they were held at the calcinations 
temperature $\left(600\right.$ or $\left.750^{\circ} \mathrm{C}\right)$ for $2 \mathrm{~h}$.

In case of sudden heating and in order to compare sudden and slow heating, only twenty $g$ of the sample number three (S3) was fed in a porcelain crucible and was loaded into the furnace directly at $750{ }^{\circ} \mathrm{C}$ for $2 \mathrm{~h}$.

The extracted silica of all chemical and thermal procedures were then analyzed using XRF apparatus model (PANalytical Axios advanced, Netherlands).

In addition, XRD was also used to examine the amorphous nature of the extracted silica as well as the presences of some unburned carbon. XRD patterns were obtained by using Rigaku RINT 2100 apparatus, in the range of $2 \theta$ from $10^{\circ}$ to $80^{\circ}$ with an intervals and scanning rate of $0.02^{\circ}$ and $5^{\circ} \mathrm{min}^{-1}$, respectively. The apparatus was outfitted with $\mathrm{Cu} \mathrm{K} \alpha$ radiation $(\lambda=0.1541 \mathrm{~nm})$ with tube voltage and current equal $50 \mathrm{kV}$ and $300 \mathrm{~mA}$ respectively. The detected crystalline phases were identified with the reference data compiled by the International Center for Diffraction Data (ICDD).

For preparing the glass samples an appropriate amount of $\mathrm{Na}_{2} \mathrm{O}, \mathrm{Bi}_{2} \mathrm{O}_{3}$ and $\mathrm{SiO}_{2}$ (obtained from $\mathrm{S}_{3}$ ) were weighted using an electronic balance having accuracy of $0.0001 \mathrm{~g}$. The batches were mixed in compositions $\left[\mathrm{x} \% \mathrm{Bi}_{2} \mathrm{O}_{3}\right.$. $(75-\mathrm{x}) \%$ $\mathrm{RH}-\mathrm{SiO}_{2} .25 \% \mathrm{Na}_{2} \mathrm{O}(\mathrm{x}=0,5,10,15$ and 20 wt.\%). The obtained mixed powders were melted in porcelain crucibles at $1300{ }^{\circ} \mathrm{C}$ for $2 \mathrm{~h}$ using an electric furnace, and they were stirred several times during melting in order to obtain homogeneous glass samples. Then the melts were quenched in air between two copper plates. Just, after sitting the solid glasses were directly transferred to the annealing furnace at $350{ }^{\circ} \mathrm{C}$ and the furnace was turned off and was left to cool to room temperature over-night.

The IR absorption spectra of the prepared glasses were recorded in the wave number range from 4000 to $400 \mathrm{~cm}^{-1}$ by using a Fourier transform computerized IR spectrometer type (JASCOo FT/IR-430, Japan). The glasses were investigated in the form of fine powders which were mixed with pulverized $\mathrm{KBr}$ in the ratio $(3: 200 \mathrm{mg}$ glass to $\mathrm{KBr}$, respectively). The weighted mixture was then pressed to produce clear homogeneous discs. The IR absorption spectra were measured immediately after preparing the desired discs.

\section{Results of Enrichment of Silica}

Egyptian RH was treated chemically and thermally in various ways in order to elevate both the concentration and purity of the extracted silica. The XRF results of the chemically treated samples $\left(\mathrm{S}_{1}, \mathrm{~S}_{2}\right.$ and $\left.\mathrm{S}_{3}\right)$ slowly heated at 600 or $750{ }^{\circ} \mathrm{C}$ for calcinations, are all exhibited in Table 1, in addition to the XRF analysis of the RH burned openly for comparison.

Table (1). XRF analysis in wt. \% for the chemically and thermally treated samples $\left(S_{1}, S_{2} \& S_{3}\right)$ slowly heated at 600 \& $750{ }^{\circ} \mathrm{C}$ and $R H$ burned openly.

\begin{tabular}{|c|c|c|c|c|c|c|c|c|c|c|c|c|c|c|}
\hline \multicolumn{3}{|c|}{$\begin{array}{l}\text { Constituents } \\
\text { (Weight \%) }\end{array}$} & \multirow{2}{*}{$\begin{array}{l}\mathrm{SiO}_{2} \\
\text { (total purity) }\end{array}$} & \multirow{2}{*}{$\begin{array}{l}\mathbf{K}_{\mathbf{2}} \mathbf{O} \\
8.78\end{array}$} & \multirow{2}{*}{$\begin{array}{l}\mathrm{CaO} \\
6.03\end{array}$} & \multirow{2}{*}{$\begin{array}{l}\mathrm{Fe}_{\mathbf{2}} \mathrm{O}_{\mathbf{3}} \\
3.51\end{array}$} & \multirow{2}{*}{$\begin{array}{l}\mathrm{MnO}_{2} \\
1.10\end{array}$} & \multirow{2}{*}{$\begin{array}{l}\mathbf{T i O}_{2} \\
0.31\end{array}$} & \multirow{2}{*}{$\begin{array}{l}\mathrm{CuO} \\
0.18\end{array}$} & \multirow{2}{*}{$\begin{array}{l}\mathbf{N i O} \\
0.11\end{array}$} & \multirow{2}{*}{$\begin{array}{l}\mathrm{Cr}_{\mathbf{2}} \mathrm{O}_{\mathbf{3}} \\
0.08\end{array}$} & \multirow{2}{*}{$\begin{array}{l}\text { Cl } \\
8.9\end{array}$} & \multirow{2}{*}{$\begin{array}{l}\text { SO } \\
3 \\
2.0\end{array}$} & \multirow{2}{*}{$\begin{array}{l}\text { Carbon } \\
\text { residue }\end{array}$} \\
\hline \multirow{7}{*}{ 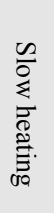 } & $\mathrm{RH}$ & & & & & & & & & & & & & \\
\hline & & $\mathrm{S}_{1}$ & 89.9 & 2.85 & 2.03 & 2.5 & 1.08 & 0.23 & 0.12 & 0.09 & 0.06 & --- & --- & 2.14 \\
\hline & 28 & $\mathrm{~S}_{2}$ & 92.9 & 1.05 & 1.97 & 1.42 & 0.62 & 0.10 & 0.08 & 0.04 & 0.021 & --- & --- & 1.80 \\
\hline & & $\mathrm{S}_{3}$ & 94.6 & 0.88 & 1.89 & 0.97 & 0.12 & 0.23 & 0.10 & 0.09 & 0.08 & --- & --- & 1.04 \\
\hline & & $\mathrm{S}_{1}$ & 91.3 & 1.03 & 2.71 & 3.04 & 0.16 & 0.10 & 0.09 & 0.011 & 0.035 & --- & --- & 1.52 \\
\hline & $\Omega$ पू & $\mathrm{S}_{2}$ & 96.5 & 0.886 & 1.54 & 0.713 & 0.102 & 0.087 & 0.057 & 0.015 & 0.019 & --- & --- & 0.08 \\
\hline & & $\mathrm{S}_{3}$ & 98.6 & 0.23 & 0.688 & 0.28 & 0.042 & 0.08 & 0.05 & 0.01 & 0.011 & --- & --- & ------ \\
\hline
\end{tabular}

Inspecting the obtained values, it can be observed that sample $\mathrm{S}_{3}$ slowly heated up to $750{ }^{\circ} \mathrm{C}$, calcinated for $2 \mathrm{~h}$, possess the highest amount of silica (98.6\%) and the lowest amount of $\mathrm{K}_{2} \mathrm{O}$ content, in comparison with all other samples as well as that of the $\mathrm{RH}$ burned openly which possess only $61.4 \%$ of silica, $7.6 \%$ carbon black and $8.78 \mathrm{~K}_{2} \mathrm{O}$.

On the other hand and in order to show the effect of sudden heating, the $\mathrm{S}_{3}$ sample after chemically treated was subjected to sudden heating at $750{ }^{\circ} \mathrm{C}$, and the obtained results are exhibited in Table (2) together with the obtained values of the same sample when slowly heated, for comparison. From the exhibited data, it can be seen that, $\mathrm{S}_{3}$ slowly heated is the best sample, since it contains the highest silica content and the lowest impurities, especially $\mathrm{K}_{2} \mathrm{O}$, with on unburned carbon black.

Table (2). XRF analysis in wt. \% of $S_{3}$ sample slowly and suddenly heated at $750{ }^{\circ} \mathrm{C}$.

\begin{tabular}{|c|c|c|c|c|c|c|c|c|c|c|c|c|c|}
\hline $\begin{array}{l}\text { Constituent } \\
\text { (Weight \%) }\end{array}$ & & $\begin{array}{l}\mathrm{SiO}_{2} \\
\text { (total purity) }\end{array}$ & $\mathbf{K}_{2} \mathbf{O}$ & $\mathrm{CaO}$ & $\mathrm{Fe}_{2} \mathrm{O}_{3}$ & $\mathrm{MnO}_{2}$ & $\mathrm{TiO}_{2}$ & $\mathrm{CuO}$ & $\mathrm{NiO}$ & $\mathrm{Cr}_{2} \mathrm{O}_{3}$ & Cl & $\mathrm{SO}_{3}$ & $\begin{array}{l}\text { Carbon } \\
\text { residue }\end{array}$ \\
\hline slow heating & $\mathrm{S}_{3}$ & 98.6 & 0.23 & 0.688 & 0.28 & 0.042 & 0.08 & 0.05 & 0.01 & 0.011 & --- & -- & ------ \\
\hline $\begin{array}{l}\text { sudden } \\
\text { heating }\end{array}$ & $\mathrm{S}_{3}$ & 90.6 & 2.56 & 2.48 & 0.28 & 0.051 & 0.07 & 0.08 & 0.05 & 0.09 & --- & --- & 3.74 \\
\hline
\end{tabular}

The XRF data of all samples were then translated and exhibited in a histogram, where the comparison of the extracted silica from all samples becomes so easy. Such histogram can be seen in Fig. 2.

On the other hand, the untreated RH burned openly, that contains only $61.4 \%$ silica, appeared black in color indicating the presence of some unburned carbon, while all the chemically treated samples slowly heated at $750{ }^{\circ} \mathrm{C}$ appeared milky white.

It can be observed that, the chemical treatment leads to higher $\mathrm{SiO}_{2}$ contents and decreases also the amount of alkali contaminants such as $\mathrm{K}_{2} \mathrm{O}$, where the presence of potassium reduces the melting temperature of silica, but it serves as an accelerator for its crystallization during combustion. In 
addition, it may increase the alkali-aggregation reaction potential of the mixtures incorporating some black unburned carbon [26-30].

The substantial decrease in the $\mathrm{K}_{2} \mathrm{O}$ content (observed in Table 1 for acid leached $\mathrm{RH}$ is expected to decrease the crystallization probability of $\mathrm{SiO}_{2}$ during vigorous and prolonged combustions. But this lower $\mathrm{K}_{2} \mathrm{O}$ content will leads consequently to higher melting temperature of $\mathrm{SiO}_{2}$. That is, surface melting of the silicate skeleton is substantially reduced for the acid leached samples.

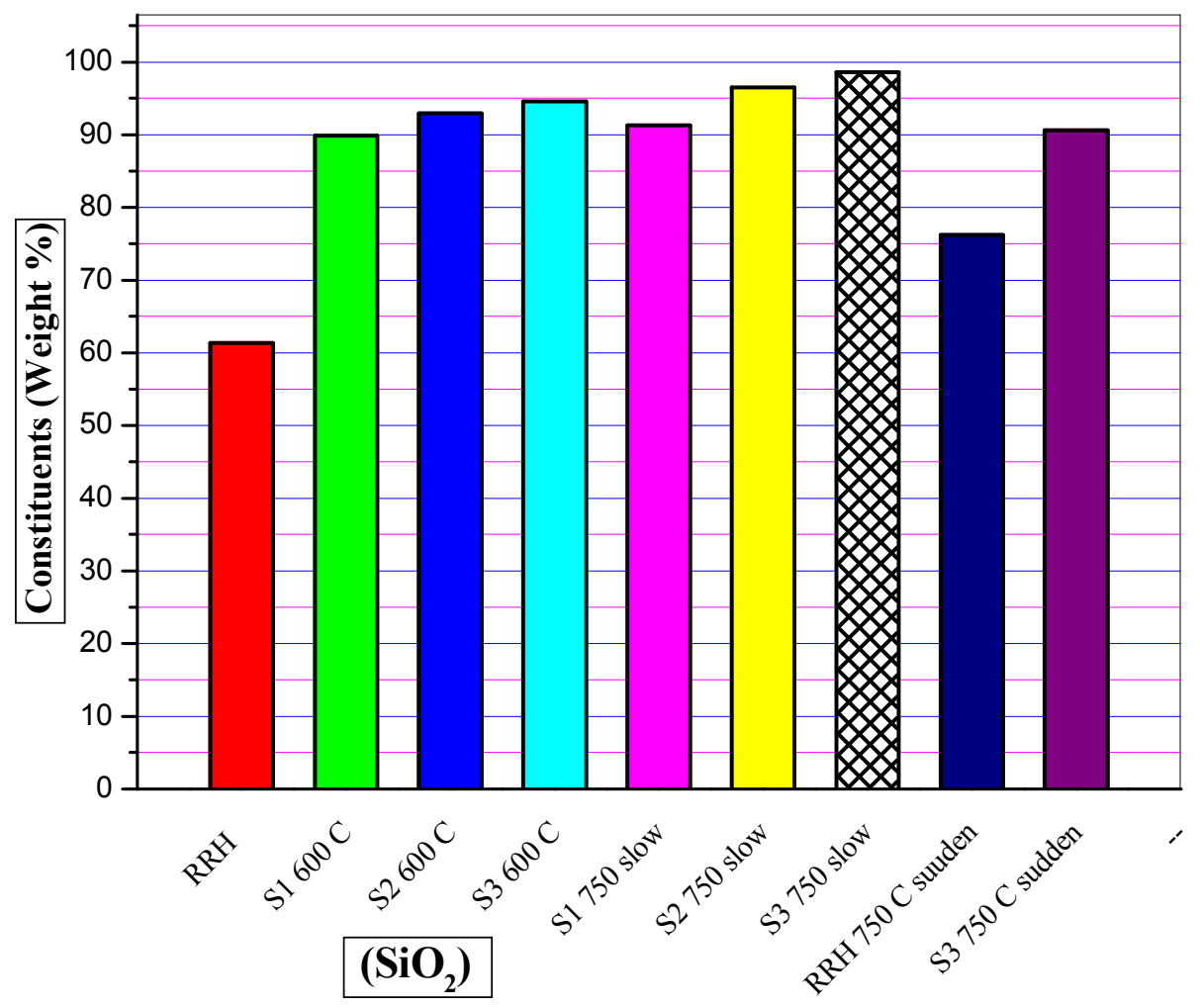

Fig. (2). The amounts of the extracted silica from all the studied samples subjected to different chemical and thermal treatment methods.

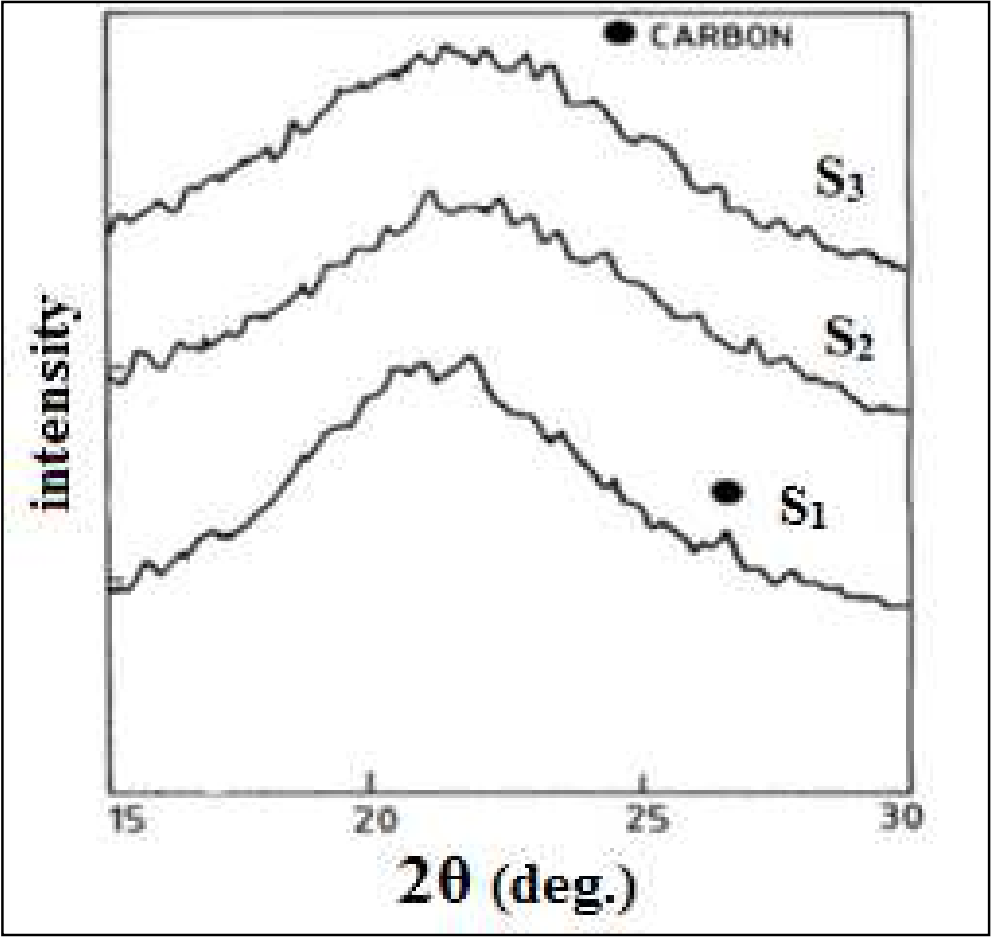

Fig. (3). XRD patterns of the extracted silica due to $S_{1}, S_{2}$ and $S_{3}$ obtained by slow heating at $750{ }^{\circ} \mathrm{C}$. 


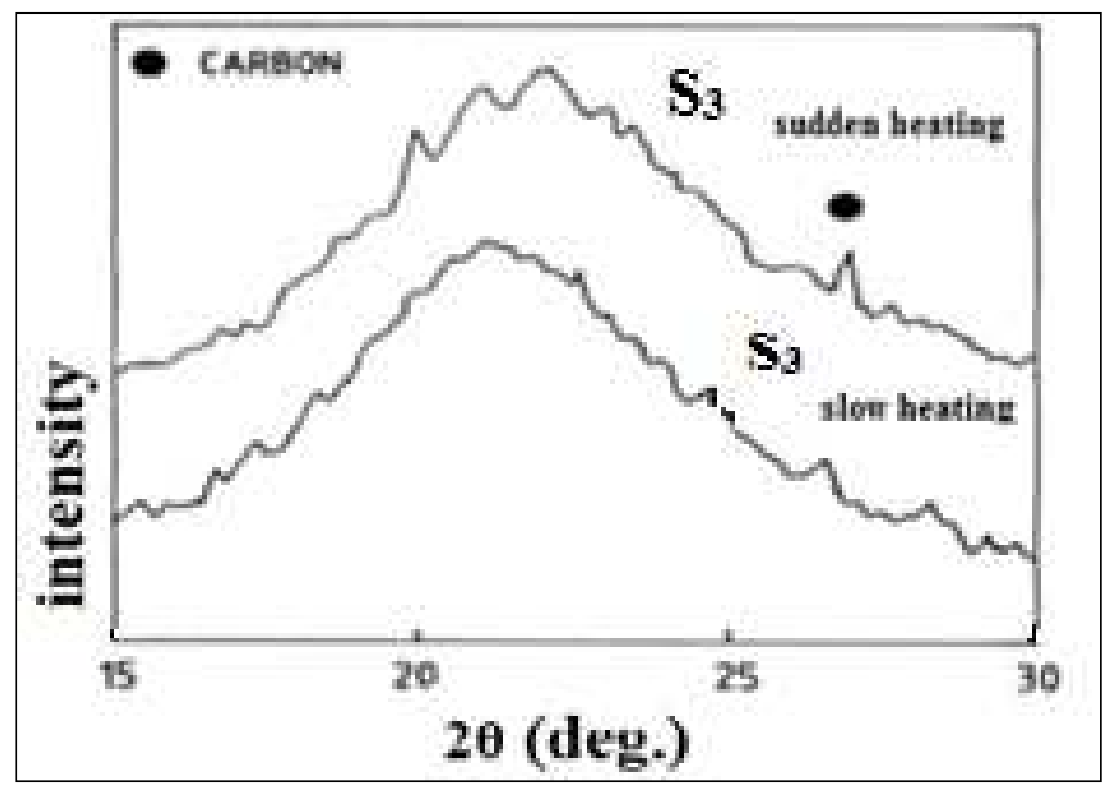

Fig. (4). XRD patterns of the extracted silica obtained from $S_{3}$ when slowly or suddenly heated at $750{ }^{\circ} \mathrm{C}$.

The brightness increased with increasing the temperature of calcinations, and rapid or sudden heating resulted in the formation of some fixed black carbon. At lower temperature $\left(600{ }^{\circ} \mathrm{C}\right), \mathrm{S}_{1}, \mathrm{~S}_{2}$ and $\mathrm{S}_{3}$ yielded charred $\mathrm{RH}$. Increasing the calcinations temperature the whiteness increased. At $750{ }^{\circ} \mathrm{C}$, the acid treated $\mathrm{RH}\left(\mathrm{S}_{1}, \mathrm{~S}_{2}\right.$ and $\left.\mathrm{S}_{3}\right)$ yielded bright white silica in comparison to other samples.

From another point of view, XRD technique has been applied to study the extracted silica whether it has crystalline or amorphous form as well as the presence of carbon black in some samples. However Fig. 3 shows the XRD patterns of $S_{1}$, $\mathrm{S}_{2}$ and $\mathrm{S}_{3}$, where, all patterns show broad hump around $2 \theta$ is about 22. These broad humps indicated that all the extracted silica showed an amorphous nature. There is no difference in XRD patterns of the $\mathrm{S}_{2}$ and $\mathrm{S}_{3}$ slowly heated at $750{ }^{\circ} \mathrm{C}$. But the XRD pattern of $S_{1}$ show a slight peak around $2 \theta=26$, indicating the presence of some unburned carbon, while both the other two patterns - due to $\mathrm{S}_{2}$ and $\mathrm{S}_{3}$ - appeared free of this peak indicating that the chemical and thermal treatments act to yield pure amorphous silica except $S_{1}$ which exhibits amorphous silica but not of high purity of all carbon black. These results were found in complete agreement with those obtained from XRF analysis.

It was observed generally that the level of impurities decreased considerably after acid treatment. The highest quantity of carbon residue was observed in the sample that suddenly heated at $750{ }^{\circ} \mathrm{C}$ only. This was clearly observed in Fig. 4 that presents the XRD patterns of $\mathrm{S}_{3}$ when slowly and suddenly heated at $750{ }^{\circ} \mathrm{C}$.

\section{Discussion of Silica Enrichment}

When RH is subjected to acid treatment, cellulose which forms the main body of $\mathrm{RH}$ is reduced and carbohydrates are blackened due to the removal of oxygen. The proteins in the RH are decomposed into amino acids and the cellulose of larger molecular weight is leached out as smaller molecular weight compounds, [31]. From the chemical analysis obtained from XRF and presented in Table 1, it can be notice that the impurities in RH are substantially removed by acid treatment. The major impurity in RH is potassium oxide and it act to accelerate the carbon fixation through $\mathrm{RH}$ silica. On the other hand, potassium oxide which dissociates upon heating at 620 ${ }^{\circ} \mathrm{C}$ forms elemental potassium whose melting point is $337^{\circ} \mathrm{C}$. However, it causes surface melting and accelerates the crystallization of amorphous silica to form cristobalite [32]. Hanafi et al [33] and Ibrahim et al [34] have studied the surface properties and crystal structure of RH silica. Crystallization was observed in the samples fired at and above $800^{\circ} \mathrm{C}$. Krishnarao et al [35] reported that a change in the morphology of $\mathrm{RH}$ silica takes place after crystallization at $1200{ }^{\circ} \mathrm{C}$.

When $\mathrm{RH}$ is heated from room temperature, the organic materials like cellulose, lignin... etc., decomposed into carbon. The rise in temperature causes oxidation of carbon. Before the removal of all carbon, if the temperature is raised to the decomposition temperature of $\mathrm{K}_{2} \mathrm{O}$ where surface melting of the ash occur, the carbon will get entrapped in the melt. If $\mathrm{RH}$ is slowly heated, the carbon could oxidize before it reaches the dissociation temperature of $\mathrm{K}_{2} \mathrm{O}$. During sudden heating of the RH silica where the samples were suddenly introduced into the furnace maintained at higher temperature. This causes simultaneous oxidation of carbon formed from decomposition of organic substances and dissociation of $\mathrm{K}_{2} \mathrm{O}$ followed by surface melting. Once carbon is entrapped in the potassium rich melt, it cannot be oxidized as it is not in direct contact with air. As the temperature of calcination increases, the tendency of carbon fixation increases during sudden heating. Therefore, a large amount of black particles were observed in the suddenly heated $\mathrm{RH}$ silica at $750{ }^{\circ} \mathrm{C}$.

During slow heating the carbon formation and its oxidation occurs before the dissociation of $\mathrm{K}_{2} \mathrm{O}$ and surface melting. So 
the tendency of silica for retention of carbon is eliminated. But the silica formed from untreated $\mathrm{RH}$ is not so bright (white) as silica formed from treated RH. This is due to the removal of impurities including potassium by acid treatment.

\section{Results and Discussion of Infrared Analysis}

According to the above studies and from the trails carried out to extract silica from $\mathrm{RH}$, it was found that, $\mathrm{S}_{3}$ slowly heated at $750{ }^{\circ} \mathrm{C}$ is the best sample that yield an amount of silica equals $98.6 \%$. Such silica will be designated in this article as RH-silica. Therefore the extracted silica from such sample was used to prepare glasses having the molecular composition $\left[\mathrm{x} \% \mathrm{Bi}_{2} \mathrm{O}_{3}(75-\mathrm{x}) \% \mathrm{SiO}_{2} 25 \% \mathrm{Na}_{2} \mathrm{O}(\mathrm{x}=0,5\right.$, 10,15 and 20 wt. \%). The internal structure of the prepared samples was thoroughly investigated by using IR spectroscopy and Fig. 5 exhibits the obtained IR spectra in the range from 400 to $4000 \mathrm{~cm}^{-1}$.

Inspecting the as measured IR spectra, it can be observed easily that the range of interest is only in between 400 to 1600 $\mathrm{cm}^{-1}$. Therefore such range was undergoing to the de-convolution technique (program) in order to inspect the functional groups in the obtained glass networks as really as possible. However Fig. 6 shows the de-convoluted IR absorption spectrum of sample no. (4) which contains $15 \mathrm{~mol} \%$ $\mathrm{Bi}_{2} \mathrm{O}_{3}$, as representative figure. The analyzed bands of all samples are summarized in Table 3.

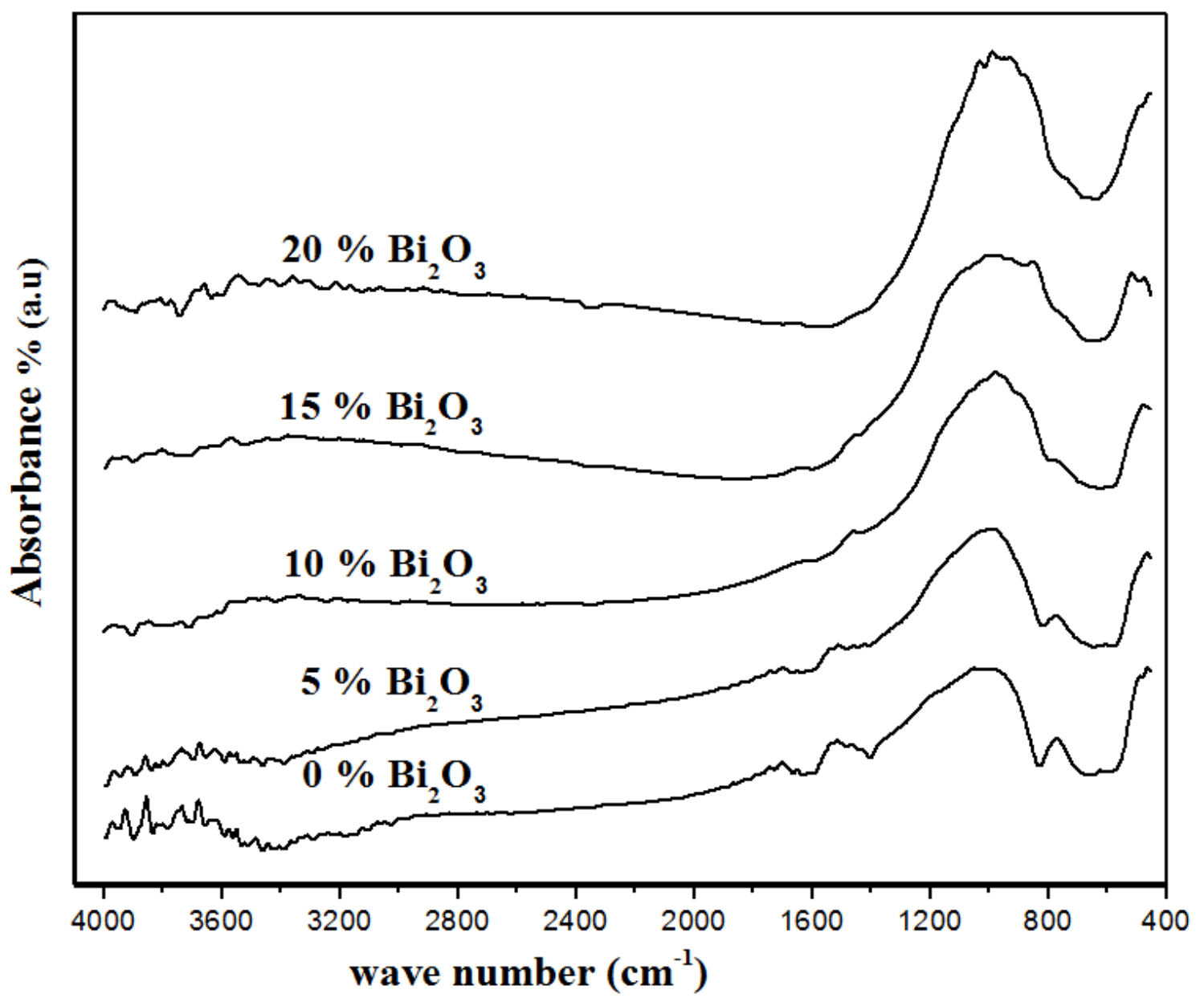

Fig. (5). The as measured IR spectra of all samples.

Table (3). The obtained IR frequencies for all glasses.

\begin{tabular}{|c|c|c|c|c|c|c|c|c|c|}
\hline Peaks & 1 & 2 & 3 & 4 & 5 & 6 & 7 & 8 & 9 \\
\hline sample 1 & 463 & 498 & 769 & 887 & 940 & 1027 & 1120 & 1181 & 1463 \\
\hline sample 2 & 456 & 507 & 738 & 872 & 919 & 1021 & 1114 & 1198 & 1465 \\
\hline sample 3 & 463 & 517 & 750 & 869 & 974 & 1025 & 1106 & 1208 & 1471 \\
\hline sample 4 & 466 & 518 & 751 & 838 & 923 & 1033 & 1149 & 1285 & 1471 \\
\hline sample 5 & 450 & 489 & 737 & 847 & 949 & 1042 & 1129 & 1213 & 1475 \\
\hline
\end{tabular}




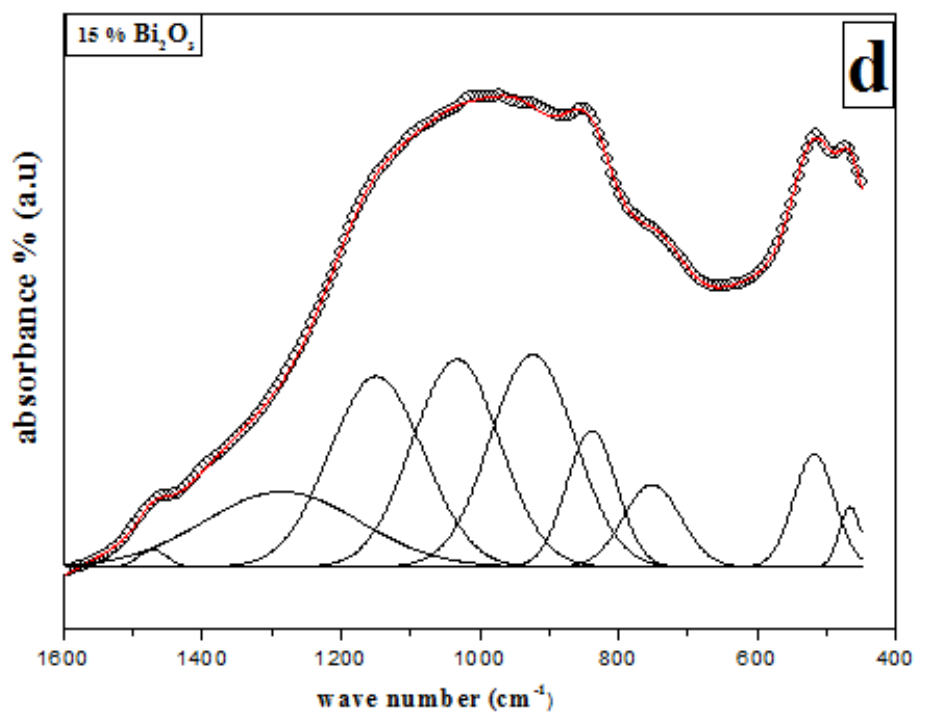

Fig. (6). The de-convoluted IR absorption spectrum of sample no. (4), as a representative figure. The effect of substituting a conventional glass former (SiO 2 ) by an unconventional glass former $\left(\mathrm{Bi}_{2} \mathrm{O}_{3}\right)$ on the structural properties of bismuth RH-silicate glasses was investigated by recording their Fourier Transform infrared (FTIR) spectra.

The positions of the absorption bands in the mid near infrared spectra of the present glasses are slightly different from the spectra usually obtained for the traditional silicate glasses and crystal [41] due to the presence of bismuth as heavy metal cations.

It was found that there appeared many IR absorption bands and these bands can be attributed to the following structural groups:

1. The band appeared in the range from 450 to $466 \mathrm{~cm}^{-1}$ can be assigned to the vibration of silicon-oxygen bonds in $\mathrm{SiO}_{4}$ tetrahedral [36-39].

2. The band appeared in the range from 489 to $518 \mathrm{~cm}^{-1}$ is assigned to Si-O-Si bending vibration [40-41]. It has been predicted by various authors [42-43] that this band may be related to $\mathrm{Bi}-\mathrm{O}$ bond vibrations in $\mathrm{BiO}_{3}$ and $\mathrm{BiO}_{6}$ octahedra. The observed shift to higher wave number $\left(518 \mathrm{~cm}^{-1}\right)$ is due to the increase of the degree of the distortion by increasing $\left(\mathrm{Bi}_{2} \mathrm{O}_{3} / \mathrm{SiO}_{2}\right)$ ratio. Dimitriev et al have also attributed the shift of the band appeared around $482-520 \mathrm{~cm}^{-1}$ to the vibration in the local symmetry of highly distorted $\mathrm{BiO}_{6}$ polyhedra and the same was also observed in IR spectra of other bismuth based glasses [44].

3. The band appeared in the range from 737 to $769 \mathrm{~cm}^{-1}$ can be assigned to $\mathrm{Si}-\mathrm{O}-\mathrm{Si}$ and $\mathrm{O}-\mathrm{Si}-\mathrm{O}$ bending modes [41].

4. The band appeared in the range from 838 to $887 \mathrm{~cm}^{-1}$ can be assigned to $\mathrm{Si}-\mathrm{O}-\mathrm{Si}$ symmetrical stretching vibration of bridging oxygen atoms between $\mathrm{SiO}_{4}$ tetrahedra [42-43]. This band appeared in the un-doped glass and its intensity showed gradual decreases as $\mathrm{Bi}_{2} \mathrm{O}_{3}$ was gradually increased accompanied by a shift to lower wavelength at 838 $\mathrm{cm}^{-1}$ which may be due to the vibration of $\mathrm{Bi}-\mathrm{O}$ linkages in $\mathrm{BiO}_{6}$ octahedral [42- 43].

5. The band appeared in the range from 919 to $949 \mathrm{~cm}^{-1}$ is assigned to $\mathrm{Si}^{-} \mathrm{O}^{-}$stretching vibration of non-bridging oxygen atoms [41].

6. The band appeared in the range from 1021 to 1042 $\mathrm{cm}^{-1}$ is due to $\mathrm{SiO}_{4}$ group bonded to two ions and the band at $1100-1150 \mathrm{~cm}^{-1}$ is associated with $\mathrm{SiO}_{4}$ tetrahedra bonded to four bridging oxygen ions [48, 49].

7. The band appeared in the range from 1181 to 1285 $\mathrm{cm}^{-1}$ is assigned to $\mathrm{Si}-\mathrm{O}-\mathrm{Si}$ anti-asymmetric stretching vibration of bridging oxygen atoms within $\mathrm{SiO}_{4}$ tetrahedra [41].

8. The band appeared in the range from 1463 to 1475 $\mathrm{cm}^{-1}$ can be assigned to the bending vibrations of $\mathrm{O}-\mathrm{H}[49]$.

9. The band appeared in the range from 1560 to 1631 $\mathrm{cm}^{-1}$ can be assigned to molecular water or hydroxyl-related bonds [50].

10. All the as measured spectra showed a water bands in the range from 3412 to $4000 \mathrm{~cm}^{-1}$, and around 2900 $\mathrm{cm}^{-1}$. These bands can be attributed to the stretching vibration of $-\mathrm{OH}$ groups. Another band appeared around $1600 \mathrm{~cm}^{-1}$ which may be due to the $-\mathrm{OH}$ bending vibration mode and some absorbed water. The presence of these bands may be due the used $\mathrm{KBr}$ technique [49-51].

From the IR structural analysis, it can be observed that there are no any band appeared due to other cations except $\mathrm{Si}$ and $\mathrm{Bi}$. This main that the impurity level is very low. It can be stated also that $\mathrm{Si}$ cations form the main glass former skeleton of the glass networks, while little $\mathrm{Bi}$ cations participate also as glass former forming $\mathrm{BiO}_{3}$ gropes. The rest of $\mathrm{Bi}$ cations act as modifier in the networks of the studied glasses forming $\mathrm{BiO}_{6}$. That is, as $\mathrm{BiO}_{3}$ was 
introduced into the glass networks at the expense of RH-silica, some Bi cations will forced to occupy the glass former positions.

\section{Conclusions}

According to the trials carried out to extract high pure concentrated silica and the IR structural analysis of the prepared glasses, the following conclusions can be drawn:

- The maximum silica content of all the chemically treated samples $\left(\mathrm{S}_{1}, \mathrm{~S}_{2}\right.$ and $\left.\mathrm{S}_{3}\right)$ slowly heated at $600{ }^{\circ} \mathrm{C}$ was presented by $\mathrm{S}_{3}$, which was found to contain $94.06 \%$. All these samples posses comparable amount of carbon black decreased on going from $\mathrm{S}_{1}$ to $\mathrm{S}_{3}$.

- On the other hand, the maximum silica content of all samples slowly heated at $750{ }^{\circ} \mathrm{C}$ was also presented by $\mathrm{S}_{3}$, but it was found to be $98.6 \%$. The black carbon appeared only in $\mathrm{S}_{1}$.

- All the extracted silica of all samples (with different chemical and thermal treatment) showed an amorphous nature.

- On trying to show the effect of sudden heating on S3 at $750{ }^{\circ} \mathrm{C}$, it can be concluded that sudden heating decreases the extracted silica content and act to induce a comparable amount of carbon black through the extracted silica.

- The extracted RH-silica can be successfully used to prepare silicate glasses with different additives used for various applications.

- The FTIR analysis showed the presence of different structural groups depends on $\mathrm{Si}^{4+}$ as former cations and the added heavy metal $\mathrm{Bi}^{3+}$ cations.

- The low impurity level and the high concentration of the RH-silica showed that RH, which is an agricultural waste, can be converted into a valuable product which has so many industrial and domestic applications.

- This study showed that rice husk can be used in many economic and technological applications, especially in the rice-producing countries like Egypt to extract highly pure silica which has various industrial and domestic applications and reduce the environmental impact of uncontrolled burning of the rice by-product.

\section{References}

[1] J. James and M. S. Rao, J. Am. Ceram. Soc. Bull, 65 (1986) 1177.

[2] F. Adam, K. Kandasamy and S. Balakrishnan, J. Colloid. Interface Sci., 304 (2006) 137.

[3] S. Maiti, S. Dey, S. Purakayastha and B. Ghosh, J. Bio-resource Technology, 97 (2006) 2065.

[4] T. J. Hyun, K. P. Yoon, S. K. Young, Y. L. Ji and M. Bhagiyalakshmi, J. Greenh. Gas Control, 3 (2009) 545.

[5] R. V. Krishnarao, J. Subrahmanyam and T. Jagadish Kumar, European Ceramic Society, 21 (2001) 99.
[6] S. Chandrasekhar, S. Satyanarayana, K. G. Pramada, P. N. Raghavan and T. N. Gupta, J. Materials Science, 38 (2003) 3159 .

[7] A. Kaupp, J. Materials Sci., 18 (1984) 303.

[8] J. Paya, J. Monzo, MV. Borrachero, A. Mellado and LM. Ordonez, J. Chem. Concr. Res, 31 (2001) 227.

[9] C. Real, M. Alcala and J. M. Criado, J. Am. Ceram. Soc., 79(8) (1996) 2012.

[10] M. Patel, A. Karera and P. Prasanna, J. Materials Sci., 22 (1987) 2457.

[11] P. C. Kapur, J. Power Technology, 44 (1985) 63.

[12] J. James and M. S. Rao, J. Thermochimica Acta, 97 (1986) 329.

[13] Liou T. Horng, J. Materials Science and Engineering, 364 (2004) 313.

[14] P. Mishra, A. Chakraverty and H.D. Banerjee, J. Mater. Sci, 20 (1985) 4387.

[15] A. Chakraverty, P. Mishra and H.D. Banerjee, J. Mater. Sci, 23 (1988) 21.

[16] J. A. Amick, J. V. Milewski and F. J. Wright, U. S. Patent No. 4,214(1980) 920 .

[17] J. A. Amick, J. Electrochem. Soc., 129 (1982) 864.

[18] L. H. Hunt, J. P. Dismukes, J. A. Amick, A. Schee, and K. Larsen, J. Electrochem. Soc., 131(7) (1984) 1683.

[19] N. Yalçin, and V. Sevinç, J. Ceramics International, 27 (2001) 219.

[20] R. V. Krishnarao, and J. Subrahmanyam, J. Ceramics International, 22 (1995) 489.

[21] P. Gorthy, and M. G. Pudukottah, J. American Ceramic Society, 82(6) (1999) 1393.

[22] T. B. Ghosh, K. C. Nandi, H. N. Acharya and D. Mukherjee, J. Material Letters, 11 (1991) 6.

[23] A. Chakraverty, P. Mishra and H. D. Banerjee, J. Thermochimica Acta, 94 (1985) 267.

[24] S. B. Hanna, L. M. Farag and N. A. L. Mansour, J. Thermochimica Acta, 81(1984) 77.

[25] V. I. E. Ajiwe, C. E. Okeke and F. C. Akigwe, J. Bio-resource Technology, 73 (2000) 37.

[26] NP. Hasparyk, PJM. Monteiro and H. Carasek, J. ACI Mater., 97 (2000) 486.

[27] A. John, S. Alexanda and A. Larry, J. International Center for Diffraction Data, 44 (2001) 368.

[28] B. M. Jenkins, L. L. Baxter, Jr. Miles and T. R. Miles, J. Fuel Processing Technology, 54 (1998) 17.

[29] J. D. Jones, J. Can. Metals, 16 (1953) 22.

[30] L. Barbieri, I. Lancellotti, T. Manfredini, I. Queralt, J.M. Rincon and M. Romero, J. Fuel, 78(1999) 271.

[31] M. Tanaka, K. Niwano and Y. Kitano, UK Patent GB2 168, (18 June 1986) 333 A. 
[32] Y. Nakata, M. Suzuki and T. Okutami. J. Thermochimica Acta, 97 (1989) 842.

[33] S. Hanafi, S. A. Abo-El-Enein, D. M. Ibrahim, and S. A. El-Hemaly, J. Thermochimica Acta, 37 (1980) 137.

[34] D. M. Ibrahim, S. A. El-Hemaly and F. M. Abdel Kerim, J. Thermochimica Acta, 37 (1980) 307.

[35] R. V. Krishnarao, J. Mater. Sci., Lett., 12 (1993) 1268.

[36] A. Witkowska, J. Rybicki and A. D. Cicco, J. Alloys Compd., $401(2005) 135$.

[37] A. DTTA, A. K. Giri and D. Chakravorty, J. Condens. Matter, 4(1992) 1783.

[38] A. Burns, H. P. Brack and W. M. J. Risen, J. Non-Cryst. Solids, 131 (1991) 994.

[39] R. S. Husung and R. H. Doremus, J. Mater. Res, 5 (1990) 2209.

[40] J. Wong and C. A. Angell, J. Mater. Sci., 9 (1967) 409.

[41] K. M. ElBadry, F. A. Moustaffa, M. A. Azooz and F. H. ElBatal, Indian J. Pure Appl. Phys., 38 (2000) 41.
[42] L. Baia, R. Stefan, W. Kiefer, J. Popp and S. Simon, J. Non-Cryst. Solids, 303 (2002) 379.

[43] F. H. ElBatal, J. Nucl. Inst. Meth. Phys. Res., 254 (2007) 243.

[44] S. Bale, M. Purnima, Ch. Srinivasu and S. Rahman, J. Alloys Compd., 457 (2008) 545.

[45] F. H. ElBatal, M. A. Azooz and F. M. Ezz ElDin, J. Phys. Chem. Glasses, 43 (5) (2002) 260.

[46] F.H. ElBatal, Egyptian J. Chem., 47 (1) (2004) 101.

[47] A. A. Akatov, B. S. Nikonov, B. I. Omelyanenko, S. V. Stefanovsky and J. C. Marra, J. Phys. Chem. Glasses, 35 (2009) 245.

[48] H. Moor and P. W. McMillan, J. Soc. Glass Technol., 40 (1956) 97.

[49] S. A. MacDonald, C. R. Schardt, D. J. Masiello and J. H. Simmons, J. Non-Cryst. Solids, 275 (2000) 72.

[50] M. S. Aziz, F. Abdel-Wahab, A. G. Mostafa and E. M. El Agwany, J. Mater. Chem. Phys., 91 (2005) 532.

[51] J. T. Quan and C. F. Adams, J. Phys. Chem., 70 (1966) 331. 